\title{
Mutations acquired during cell culture isolation may affect antigenic characterisation of influenza $\mathrm{A}(\mathrm{H} 3 \mathrm{~N} 2)$ clade 3C.2a viruses
}

\author{
DM Skowronski ${ }^{12}$, S Sabaiduc ${ }^{1}$, C Chambers ${ }^{1}$, A Eshaghi ${ }^{3}$, JB Gubbay ${ }^{34}$, M Krajden ${ }^{12}$, SJ Drews ${ }^{56}$, C Martineau ${ }^{7}$, G De \\ Serres ${ }^{789}$, JA Dickinson ${ }^{10}$, A Winter ${ }^{3}$, N Bastien ${ }^{11}, Y$ Li $^{11}{ }^{12}$ \\ 1. British Columbia Centre for Disease Control, Vancouver, Canada \\ 2. University of British Columbia, Vancouver, Canada \\ 3. Public Health Ontario, Toronto, Canada \\ 4. University of Toronto, Toronto, Canada \\ 5. University of Alberta, Edmonton, Canada \\ 6. Alberta Provincial Laboratory, Edmonton, Canada \\ 7. Institut National de Santé Publique du Québec (National Institute of Health of Quebec), Quebec, Canada \\ 8. Laval University, Quebec, Canada \\ 9. Centre Hospitalier Universitaire de Québec (University Hospital Centre of Quebec), Quebec, Canada \\ 10. University of Calgary, Calgary, Canada \\ 11. National Microbiology Laboratory, Public Health Agency of Canada, Winnipeg, Canada \\ 12. University of Manitoba, Winnipeg, Canada
}

Correspondence: Danuta M. Skowronski (danuta.skowronski@bccdc.ca)

Citation style for this article:
Skowronski D, Sabaiduc S, Chambers C, Eshaghi A, Gubbay J, Krajden M, Drews S, Martineau C, De Serres G, Dickinson J, Winter A, Bastien N, Li Y. Mutations acquired during cell culture isolation may affect antigenic characterisation of influenza A(H3N2) clade 3 C.2a viruses. Euro Surveill. 2016;21(3):pii=30112. DOI: http://dx.doi.org/10.2807/1560-7917.ES.2016.21.3.30112

Article submitted on 10 December 2015 / accepted on 21 January 2016 / published on 21 January 2016

As elsewhere, few (<15\%) sentinel influenza $\mathrm{A}\left(\mathrm{H}_{3} \mathrm{~N}_{2}\right)$ clade 3 C.2a viruses that dominated in Canada during the 2014/15 season could be antigenically characterised by haemagglutination inhibition ( $\mathrm{HI}$ ) assay. Clade 3 C.2a viruses that could be HI-characterised had acquired genetic mutations during in vitro cell culture isolation that modified the potential glycosylation motif found in original patient specimens and the consensus sequence of circulating viruses at amino acid positions 158-160 of the haemagglutinin protein. Caution is warranted in extrapolating antigenic relatedness based on limited $\mathrm{HI}$ findings for clade $3 \mathrm{C} .2 \mathrm{a}$ viruses that continue to circulate globally.

\section{Introduction}

During the $2014 / 15$ influenza $\mathrm{A}\left(\mathrm{H}_{3} \mathrm{~N}_{2}\right)$ epidemic, viruses belonging to phylogenetic clade $3 \mathrm{C} .2 \mathrm{a}$ predominated $[1,2]$. Viruses within this clade bore multiple (10-12) amino acid differences from the A/Texas/50/2012 (clade ${ }_{3}$ C.1) vaccine strain at antigenic sites of the surface haemagglutinin (HA) protein [2]. These differences included two clade-defining substitutions, a phenylalanine $(\mathrm{F})$ to tyrosine $(\mathrm{Y})$ substitution at residue 159 (F159Y) and a lysine (K) to threonine ( $\mathrm{T}$ ) substitution at the adjacent residue 160 (K160T), both in antigenic site $B[1,2]$, a highly exposed region at the top of the HA protein where mutations create the potential for viral evasion of the antibody response $[3,4]$. Together with an asparagine $(\mathrm{N})$ residue at position 158 , conserved in all clade $3 \mathrm{C}$ viruses, the N158-Y159-T160 sequon in clade 3 C.2a viruses represents a potential gain of glycosylation that can mask viral epitopes and reduce antibody access to the immuno-dominant antigenic site $B[5,6]$. This potential glycosylation motif at amino acid positions $158-160$ of the HA protein is unique to clade $3 \mathrm{C} .2 \mathrm{a}$ viruses, and is not found in other recently circulating $\mathrm{A}\left(\mathrm{H}_{3} \mathrm{~N}_{2}\right)$ genetic clades.

Koel et al. have previously highlighted positions 158 and 159 as among seven residues in the HA protein associated with all major antigenic cluster-transition events in $\mathrm{A}\left(\mathrm{H}_{3} \mathrm{~N}_{2}\right)$ viruses since 1968 [7] and in a recent serological analysis, Chambers et al. highlighted the substitution at position 159 as likely to have been responsible for the 2014/15 antigenic drift [8]. Consistent with these molecular findings, mid-season vaccine effectiveness (VE) analyses from multiple countries, including the Canadian Sentinel Practitioner Surveillance Network (SPSN), the United States (US) and the United Kingdom (UK), reported negligible protection against the $2014 / 15 \mathrm{~A}\left(\mathrm{H}_{3} \mathrm{~N}_{2}\right)$ clade $3 \mathrm{C} .2 \mathrm{a}$ epidemic strain $[2,9,10]$. In February 2015, the World Health Organization (WHO) recommended that the $\mathrm{A}\left(\mathrm{H}_{3} \mathrm{~N}_{2}\right)$ component for the $2015 / 16$ season be updated to an A/Switzerland/9715293/2013-like (clade 3C.3a) strain [11].

Influenza surveillance reports from reference laboratories globally have indicated that circulating $\mathrm{A}\left(\mathrm{H}_{3} \mathrm{~N}_{2}\right)$ viruses belonging to clade $3 \mathrm{C} .2 \mathrm{a}$ are antigenically 
Haemagglutination inhibition assay titres and fold reductions relative to cell- and egg-passaged A/Switzerland/9715293/2013 reference virus for sentinel A(H3N2) virus isolates with known genetic clade, Canadian Sentinel Practitioner Surveillance Network, November 2014-April 2015 ( $\mathrm{n}=49)$

\begin{tabular}{|c|c|c|c|c|c|c|c|c|}
\hline \multirow{2}{*}{$\begin{array}{l}\text { Sentinel isolate } \\
\text { (clade) }\end{array}$} & \multicolumn{4}{|c|}{$\begin{array}{c}\text { Cell-passaged } \\
\text { A/Switzerland/9715293/2013 } \\
(n=49)\end{array}$} & \multicolumn{4}{|c|}{$\begin{array}{c}\text { Egg-passaged } \\
\text { A/Switzerland } / 9715293 / 2013 \\
\left(\mathrm{n}=35^{\mathrm{a}}\right)\end{array}$} \\
\hline & $n$ & $\begin{array}{l}\text { Sentinel } \\
\text { isolate } \\
\text { HI titre range }\end{array}$ & $\begin{array}{l}\text { Homologous } \\
\text { reference virus } \\
\text { HI titre range }\end{array}$ & $\begin{array}{l}\text { Fold } \\
\text { reduction }\end{array}$ & $n$ & $\begin{array}{l}\text { Sentinel } \\
\text { isolate } \\
\text { HI titre range }\end{array}$ & $\begin{array}{l}\text { Homologous } \\
\text { reference virus } \\
\text { HI titre range }\end{array}$ & $\begin{array}{l}\text { Fold } \\
\text { reduction }\end{array}$ \\
\hline Clade $3 \mathrm{C} .2 \mathrm{a}$ & 31 & $80-160$ & $320-640$ & $\leq 4$ & 25 & $160-320$ & $320-640$ & $\leq 4$ \\
\hline Clade 3 C.3 & 1 & 160 & 320 & 2 & 1 & 320 & 640 & 2 \\
\hline Clade 3 C.3a & 2 & $160-640$ & $320-640$ & $\leq 4$ & 2 & 320 & $320-640$ & $\leq 2$ \\
\hline Clade $3 \mathrm{C} .3 \mathrm{~b}$ & 15 & $80-1,280$ & 320 & $\leq 4$ & 7 & $80-640$ & $320-640$ & $\leq 8^{\mathrm{b}}$ \\
\hline
\end{tabular}

HI: haemagglutination inhibition.

a These 35/49 viruses were characterised in relation to both the cell-passaged and egg-passaged A/Switzerland/9715293/2013 reference virus. For the other $14 / 49$ viruses initially characterised in relation to the cell-passaged A/Switzerland/9715293/2013 reference virus, there remained insufficient viral titre to support further characterisation in relation to the egg-passaged reference virus.

${ }^{b}$ One clade 3 C.3b virus had an eightfold reduction to egg-passaged A/Switzerland/9715293/2013 reference virus; all other tested viruses had $\leq 4$-fold reductions.

\section{TABLE 2}

Potential glycosylation motif at haemagglutinin positions 158-160 in influenza A(H3N2) clade 3C.2a viruses from original patient specimens and culture isolates prior to haemagglutination inhibition assay by the NML, Canadian Sentinel Practitioner Surveillance Network, November 2014-April $2015(\mathrm{n}=234)$

\begin{tabular}{|c|c|c|c|c|c|c|}
\hline \multirow{3}{*}{$\begin{array}{l}\text { HI assay } \\
\text { characterisation }\end{array}$} & \multicolumn{6}{|c|}{ HA amino acid sequence at positions $158-159-160$} \\
\hline & \multicolumn{3}{|c|}{$\begin{array}{l}\text { Original patient specimens } \\
\qquad n=234\end{array}$} & \multicolumn{3}{|c|}{$\begin{array}{l}\text { Culture isolates } \\
\qquad n=234\end{array}$} \\
\hline & $\begin{array}{l}N-Y-T^{a} \\
n=219\end{array}$ & $\begin{array}{l}\text { Not } \\
N-Y-T \\
n=2\end{array}$ & $\begin{array}{l}\text { Sequence not available } \\
\qquad n=13\end{array}$ & $\begin{array}{l}N-Y-T^{a} \\
n=156\end{array}$ & $\begin{array}{l}\text { Not or poly } \\
\begin{array}{c}N-Y-T \\
n=71\end{array}\end{array}$ & $\begin{array}{l}\text { Sequence not available } \\
n=7\end{array}$ \\
\hline $\begin{array}{l}\text { Sufficient HA titre for HI assayb } \\
(n=31)\end{array}$ & $26(12)$ & 1 & 4 & o (o) & $28(39)$ & 3 \\
\hline $\begin{array}{l}\text { Insufficient HA titre for HI assay } \\
(n=203)\end{array}$ & $193(88)$ & 1 & 9 & $156(100)$ & $43(61)$ & 4 \\
\hline
\end{tabular}

HA: haemagglutinin; HI: haemagglutination inhibition; NML: National Microbiology Laboratory; poly: polymorphic for the N-Y-T amino acid sequence (i.e. partial loss of the potential glycosylation motif).

Values displayed are: number (\% column).

${ }^{a}$ A potential glycosylation motif is defined by the amino acid sequon: $\mathrm{N}-\mathrm{X}-\mathrm{T} / \mathrm{S}$; where $\mathrm{N}$ is asparagine, $\mathrm{X}$ is any amino acid other than proline and $T / S$ is either threonine or serine $[5,6]$. The consensus sequence for clade 3 C.2a viruses is N158-Y159-T160, conferring a potential gain of glycosylation.

${ }^{b}$ In the presence of $20 \mathrm{nM}$ oseltamivir.

related to $\mathrm{A} /$ Switzerland/9715293/2013, despite the fact that only a small proportion could be characterised by conventional haemagglutination inhibition $(\mathrm{HI})$ assay $[1,12,13]$. Influenza $A\left(\mathrm{H}_{3} \mathrm{~N}_{2}\right)$ viruses have been difficult to characterise antigenically by $\mathrm{HI}$ assay due to variable agglutination of erythrocytes or loss of ability to agglutinate erythrocytes, a particular problem for clade $3 \mathrm{C} .2 \mathrm{a}$ viruses [1]. For the majority of $\mathrm{A}\left(\mathrm{H}_{3} \mathrm{~N}_{2}\right)$ viruses that could not be $\mathrm{HI}$-characterised, reference laboratories have imputed antigenic relatedness based on sequencing findings, assuming that viruses that could be characterised within a given genetic group or clade are broadly representative of circulating strains $[12,13]$.
The European Centre for Disease Prevention and Control (ECDC) has earlier highlighted that clade 3 C.2a viruses that had sufficient HA titre to agglutinate erythrocytes and that could be characterised by $\mathrm{HI}$ assay had either lost or were polymorphic for the clade-defining glycosylation motif at positions 158-160 [14]. To assess the representativeness of clade 3 C.2a viruses that could be characterised by $\mathrm{HI}$ assay, we examined amino acid identity at positions $158-160$ for the presence of this potential glycosylation motif in original patient specimens collected by the Canadian SPSN compared with the corresponding sequence after cell culture isolation of virus during the $2014 / 15$ season. 


\section{Methods}

Nasal/nasopharyngeal specimens collected from patients within seven days of influenza-like illness onset through the Canadian SPSN between 1 November 2014 and 30 April 2015 were tested for influenza by RT-PCR. Influenza-positive specimens were inoculated into Madin-Darby Canine Kidney (MDCK), MDCK-SIAT1 or Rhesus Monkey Kidney (RMK) cells to attempt culture isolation as per provincial reference laboratory protocols. Cell culture isolates were submitted to Canada's National Microbiology Laboratory (NML) for antigenic characterisation by standard $\mathrm{HI}$ assay protocols using guinea pig erythrocytes and post-infection ferret antisera supplied by the US Centers for Disease Control and Prevention (US CDC) raised against celland egg-passaged A/Switzerland/9715293/2013 reference viruses [2]. To circumvent any neuraminidase (NA)-mediated binding of $\mathrm{A}\left(\mathrm{H}_{3} \mathrm{~N}_{2}\right)$ viruses to erythrocytes, $\mathrm{HI}$ assays were conducted in the presence of 20 nM oseltamivir carboxylate following, where indicated, a further single passage in MDCK-SIAT1 cells at the NML to improve viral titres $[15,16]$. Antigenic relatedness of a sentinel isolate to A/Switzerland/9715293/2013 reference virus was defined as a $\leq 4$-fold reduction in $\mathrm{HI}$ antibody titre compared to the titre of the homologous reference virus [17].

Sanger sequencing of the viral HA gene was conducted on the original patient specimens to establish clade designation and to detect amino acid substitutions in $\mathrm{HA}$ antigenic sites. For the current study, sequencing was also conducted on cultured isolates of clade $3 \mathrm{C} .2 \mathrm{a}$ viruses before and after further passage in MDCK-SIAT1 cells (if indicated) prior to $\mathrm{HI}$ characterisation at the NML to assess amino acid identity relative to the clade 3C.2a N158-Y159-T160 consensus sequence and to sequences based on the corresponding original patient specimen. Ethics boards in each participating province approved the SPSN VE study of which this virological sub-analysis is a component; virus characterisation was also conducted as part of national surveillance activities.

\section{Results}

\section{Clade distribution and $\mathrm{HI}$ characterisation}

Of the 460 influenza $A\left(\mathrm{H}_{3} \mathrm{~N}_{2}\right)$ detections by the SPSN during the $2014 / 15$ season with known clade information, 265 (58\%) virus isolates were cultivated by provincial reference laboratories and submitted to the NML for antigenic characterisation by $\mathrm{HI}$ assay. Of the 265 virus isolates, 197 (74\%) were grown by provincial laboratories in MDCK, 44 (17\%) in MDCK-SIAT1 and 24 ( $9 \%)$ in RMK cells. Submitted $\mathrm{A}\left(\mathrm{H}_{3} \mathrm{~N}_{2}\right)$ virus isolates included 234 (88\%) viruses belonging to clade $3 \mathrm{C} .2 \mathrm{a}$, 25 ( $9 \%$ ) belonging to clade $3 \mathrm{C} .3 \mathrm{~b}$, four ( $2 \%$ ) belonging to clade 3 C.3 and two (1\%) belonging to clade 3 C.3a, reflecting the overall clade distribution and clade $3 \mathrm{C} .2 \mathrm{a}$ predominance among sentinel $\mathrm{A}\left(\mathrm{H}_{3} \mathrm{~N}_{2}\right)$ detections previously reported [2].
Of these 265 virus isolates with known clade information, $49(18 \%)$ had sufficient HA titre to agglutinate erythrocytes and could be characterised by $\mathrm{HI}$ assay. These included only 31 (13\%) of the 234 virus isolates belonging to clade 3 C.2a. By comparison, of the 31 non-clade 3 C.2a virus isolates, 18 could be characterised by $\mathrm{HI}$, including 15 of 25 belonging to clade $3 \mathrm{C} .3 \mathrm{~b}$, one of four belonging to 3 C.3, and both of the virus isolates belonging to clade 3 C.3a.

All 49 virus isolates that could be $\mathrm{HI}$-characterised were considered antigenically related to the cell-passaged A/Switzerland/9715293/2013 vaccine prototype recommended for the $2015 / 16$ vaccine. A subset of 35 of the 49 viruses was additionally characterised against the egg-passaged A/Switzerland/9715293/2013 vaccine reference and 34 of them were considered antigenically related; one clade 3 C.3b virus showing eightfold titre reduction was considered antigenically distinct (Table 1).

Clade 3C.2a viruses and the $158-160$ sequon Of the 234 clade 3 C.2a virus isolates submitted to NML, sequencing of the viral HA at positions $158-160$ based on original patient specimens was successful for 221 (94\%) viruses (Table 2). Of these 221 viruses from original patient specimens, 219 (99\%) bore the clade $3 \mathrm{C} .2 \mathrm{a}$ consensus sequence N158-Y159-T160 consistent with the potential glycosylation motif and two (1\%) instead bore $\mathrm{K}_{160}$ found otherwise in clade $3 \mathrm{C} .2$ viruses.

Following cell culture isolation at provincial reference laboratories, 229 of 234 (98\%) clade 3C.2a virus isolates had sequencing information available before MDCK-SIAT1 passage (if indicated) at the NML. Of these, 63 (28\%) viruses had lost or partially lost (i.e. become polymorphic for) the N158-Y159-T160 consensus sequence, including 45 (25\%) of 178 grown in MDCK, 10 of 30 grown in MDCK-SIAT1 and eight of 21 grown in RMK cells.

Of the 31 clade 3 C.2a viruses that could be $\mathrm{HI}$-characterised, 17 had undergone a single further passage in MDCK-SIAT1 cells at the NML prior to $\mathrm{HI}$ assay. Sequencing information was available for 15 of these 17 viruses that required additional MDCK-SIAT1 passage and 13 of the 14 viruses that did not require further MDCK-SIAT1 passage. Based on available sequencing information, all 28 viruses had lost or were polymorphic for the potential glycosylation motif (Table 2). For all but two of the virus isolates that were further passaged in MDCK-SIAT1 cells at the NML, sequences were identical before and after that passage. Of the two viruses modified with MDCK-SIAT1 passage at the $\mathrm{NML}$, one isolate that was polymorphic after initial cell culture lost the potential glycosylation motif and one isolate that maintained the original consensus sequence after initial cell culture became polymorphic after MDCK-SIAT1 passage. 


\section{TABLE 3}

Amino acid sequence at haemagglutinin positions 158-160 of influenza A(H3N2) clade 3C.2a viruses with respect to the potential glycosylation motif in final culture isolates prior to haemagglutination inhibition assay by the NML, Canadian Sentinel Practitioner Surveillance Network, November 2014-April 2015 (n=234)

\begin{tabular}{|c|c|c|c|c|c|}
\hline \multicolumn{3}{|c|}{ HA amino acid sequence } & \multirow{2}{*}{ Glycosylation motif } & \multirow{2}{*}{$\begin{array}{c}\text { Frequency } \\
\text { n (\%) }\end{array}$} & \multirow{2}{*}{ Interpretation } \\
\hline 158 & 159 & 160 & & & \\
\hline \multicolumn{6}{|c|}{ Consensus sequence in circulating clade $3 \mathrm{C} .2 \mathrm{a}$ viruses } \\
\hline $\mathrm{N}$ & $\mathrm{Y}$ & $\mathrm{T}$ & $+\mathrm{CHO}$ & & \\
\hline \multicolumn{6}{|c|}{ Sequence after final cell culture ${ }^{a}$} \\
\hline \multicolumn{6}{|c|}{$A\left(\mathrm{H}_{3} \mathrm{~N}_{2}\right)$ clade $3 \mathrm{C} .2 \mathrm{a}$ viruses with sufficient $\mathrm{HA}$ titre for $\mathrm{HI} \mathrm{assay}^{b}(n=31)$} \\
\hline $\mathrm{N}$ & $\mathrm{Y}$ & $\mathrm{K}$ & $-\mathrm{CHO}$ & 8 & Reversion to clade $3 \mathrm{C} .2 \mathrm{~K} 160$ \\
\hline $\mathrm{N}$ & $\mathrm{Y}$ & A & $-\mathrm{CHO}$ & 7 & New T16oA mutation \\
\hline $\mathrm{N}$ & $\mathrm{Y}$ & $\mathrm{T} / \mathrm{K}$ & Polymorphic ${ }^{\mathrm{c}}$ & 4 & Partial reversion to clade $3 \mathrm{C}_{2} \mathrm{~K} \mathrm{~K}_{160}$ \\
\hline $\mathrm{K}$ & $\mathrm{Y}$ & $\mathrm{T}$ & $-\mathrm{CHO}$ & 3 & New N158K mutation \\
\hline $\mathrm{N}$ & $\mathrm{Y}$ & 1 & $-\mathrm{CHO}$ & 3 & New T16ol mutation \\
\hline $\mathrm{D}$ & $\mathrm{Y}$ & $T$ & $-\mathrm{CHO}^{\mathrm{d}}$ & 1 & New N158D mutation \\
\hline $\mathrm{H}$ & $\mathrm{Y}$ & $T$ & $-\mathrm{CHO}$ & 1 & New N158H mutation \\
\hline $\mathrm{N} / \mathrm{S}$ & $\mathrm{Y}$ & $T$ & Polymorphic & 1 & Polymorphic for new N158S mutation \\
\hline \multicolumn{3}{|c|}{ Sequence not available } & NA & 3 & NA \\
\hline \multicolumn{6}{|c|}{$A\left(\mathrm{H}_{3} \mathrm{~N}_{2}\right)$ clade $3 \mathrm{C} .2 \mathrm{a}$ viruses with insufficient $\mathrm{HA}$ titre for $\mathrm{HI}_{\text {assay }}{ }^{b}(n=203)$} \\
\hline $\mathrm{N}$ & $\mathrm{Y}$ & $\mathrm{T}$ & $+\mathrm{CHO}$ & $156(77)$ & Consensus clade $3 \mathrm{C} .2 \mathrm{a}$ sequence \\
\hline $\mathrm{N} / \mathrm{K}$ & $\mathrm{Y}$ & $\mathrm{T}$ & Polymorphic & $6(3)$ & Polymorphic for new N158K mutation \\
\hline N/D & $\mathrm{Y}$ & $\mathrm{T}$ & Polymorphic & $5(2)$ & Polymorphic for new N158D mutation \\
\hline $\mathrm{N}$ & $\mathrm{Y}$ & $\mathrm{T} / \mathrm{I}$ & Polymorphic & $5(2)$ & Polymorphic for new T16ol mutation \\
\hline $\mathrm{N}$ & $\mathrm{Y}$ & T/A & Polymorphic & $5(2)$ & Polymorphic for new T16oA mutation \\
\hline $\mathrm{N}$ & $\mathrm{Y}$ & $\mathrm{T} / \mathrm{K}$ & Polymorphic & $5(2)$ & Partial reversion to clade ${ }_{3} \mathrm{C} .2 \mathrm{~K} 160$ \\
\hline $\mathrm{N}$ & $\mathrm{Y}$ & A & $-\mathrm{CHO}$ & $3(1)$ & New T16oA mutation \\
\hline $\mathrm{N}$ & $\mathrm{Y}$ & 1 & $-\mathrm{CHO}$ & $3(1)$ & New T16ol mutation \\
\hline $\mathrm{N}$ & $\mathrm{Y}$ & $\mathrm{K}$ & $-\mathrm{CHO}$ & $3(1)$ & Reversion to clade $3 \mathrm{C} .2 \mathrm{~K} 160$ \\
\hline $\mathrm{S}$ & $\mathrm{Y}$ & $\mathrm{T}$ & $-\mathrm{CHO}$ & $2(1)$ & New N158S mutation \\
\hline $\mathrm{D}$ & $\mathrm{Y}$ & $T$ & $-\mathrm{CHO}$ & $1(0)$ & New N158D mutation \\
\hline $\mathrm{K}$ & $\mathrm{Y}$ & $T$ & $-\mathrm{CHO}$ & $1(0)$ & New N158K mutation \\
\hline $\mathrm{N} / \mathrm{K}$ & $\mathrm{Y}$ & $\mathrm{T} / \mathrm{I}$ & Polymorphic & $1(0)$ & Polymorphic for new N158K and T16ol mutations \\
\hline$N / R$ & $\mathrm{Y}$ & $\mathrm{T} / \mathrm{I}$ & Polymorphic & $1(0)$ & Polymorphic for new N158R and T16ol mutations \\
\hline $\mathrm{N} / \mathrm{S}$ & $\mathrm{Y}$ & T/A & Polymorphic & $1(0)$ & Polymorphic for new N158S and T16oA mutations \\
\hline $\mathrm{N} / \mathrm{K} / \mathrm{R} / \mathrm{S}$ & $\mathrm{Y}$ & $\mathrm{T}$ & Polymorphic & $1(0)$ & Polymorphic for new N158K/R/S mutation \\
\hline \multicolumn{3}{|c|}{ Sequence not available } & NA & $4(2)$ & NA \\
\hline
\end{tabular}

CHO: carbon-hydrogen-oxygen (i.e. glycosylation); HA: haemagglutinin; HI: haemagglutination inhibition; NA: not available; NML: National Microbiology Laboratory.

$+\mathrm{CHO}$ : potential glycosylation motif in clade 3 C.2a viruses defined by the amino acid sequon: N158-Y159-T16o [5,6]; - CHO: loss of this potential glycosylation motif; Polymorphic: partial loss of the glycosylation motif.

Mutations at residues 158-160 compared with the consensus sequence for clade 3 C.2a viruses are shaded in blue: dark blue shading indicates amino acid mutation relative to the consensus sequence; light blue shading indicates polymorphism relative to the consensus sequence. Two viruses were N158-Y159-K160 (- CHO) in the original patient specimen, including one that could and one that could not be HI-characterised.

a Final available sequence of virus isolates prior to $\mathrm{HI}$ characterisation is shown. Of the 234 viruses sent to the NML, 220 were re-passaged in MDCK-SIAT1 cells to attempt to improve virus titre, including 17 of 31 that could be HI-characterised and all 203 that could not be HIcharacterised. Sequences for cell culture isolates as submitted from provincial reference laboratories are shown for the 13 of 14 viruses with available sequence information that could be HI-characterised without further passage in MDCK-SIAT1 cells at the NML.

${ }^{b}$ In the presence of $20 \mathrm{nM}$ oseltamivir.

c One of these four viruses was T16o (i.e. + $\mathrm{CHO}$ ) in the cell culture isolate before further MDCK-SIAT1 passage at the NML but became polymorphic after MDCK-SIAT1-passage with partial reversion to T/K160 (i.e. N158-Y159-T/K160).

${ }^{d}$ This virus was polymorphic for the glycosylation motif with N/D158 in the cell culture isolate before MDCK-SIAT1 passage at the NML but lost the potential glycosylation motif (i.e. became - CHO) after MDCK-SIAT1 passage with D158 (i.e. D158-Y159-T160). 
TABLE 4

Reference haemagglutinin sequences from the GISAID EpiFlu database used to assess the 158-160 sequon in the southern hemisphere 2016 influenza A(H3N2) cell- and egg-passaged vaccine reference strain A/Hong Kong/4801/2014 (clade 3C.2a)

\begin{tabular}{|c|c|c|c|c|c|c|c|}
\hline Segment ID & $\begin{array}{l}\text { Collection } \\
\text { date }\end{array}$ & Isolate name ${ }^{a}$ & $\begin{array}{l}\text { Originating } \\
\text { laboratory }\end{array}$ & $\begin{array}{l}\text { Submitting } \\
\text { laboratory }\end{array}$ & Authors & Passage history & $\begin{array}{c}158-159-160 \\
\text { sequon }^{b}\end{array}$ \\
\hline $\mathrm{EPI}_{539576}$ & 26 Feb 2014 & $\begin{array}{c}\text { A/Hong } \\
\text { Kong/4801/2014 }\end{array}$ & $\begin{array}{l}\text { Government } \\
\text { Virus Unit }\end{array}$ & $\begin{array}{l}\text { National } \\
\text { Institute } \\
\text { for Medical } \\
\text { Research } \\
\end{array}$ & & MDCK-SIAT1 & $N-Y-T$ \\
\hline EPI578430 & 1 Jan 2014 & $\begin{array}{c}\text { A/Hong } \\
\text { Kong/4801/2014 }\end{array}$ & $\begin{array}{c}\text { Crick Worldwide } \\
\text { Influenza } \\
\text { Centre }\end{array}$ & $\begin{array}{c}\text { Centers for } \\
\text { Disease Control } \\
\text { and Prevention }\end{array}$ & & $\mathrm{E}_{5} / \mathrm{E}_{1}$ & $N-Y-K$ \\
\hline EPI643118 & 26 Feb 2014 & $\begin{array}{c}\text { A/Hong } \\
\text { Kong/4801/2014 }\end{array}$ & $\begin{array}{c}\text { Crick Worldwide } \\
\text { Influenza } \\
\text { Centre }\end{array}$ & $\begin{array}{c}\text { National } \\
\text { Institute of } \\
\text { Infectious } \\
\text { Diseases (NIID) }\end{array}$ & $\begin{array}{c}\text { Takashita, Emi; } \\
\text { Fujisaki, Seiichiro; } \\
\text { Shirakura, } \\
\text { Masayuki; } \\
\text { Watanabe, Shinji; } \\
\text { Odagiri, Takato }\end{array}$ & $\mathrm{E} 6(\mathrm{Am} 1 \mathrm{Al}) / \mathrm{E}_{1}+1$ & $N-Y-K$ \\
\hline EPI614406 & 1 Jan 2014 & $\begin{array}{c}\text { A/Hong } \\
\text { Kong/4801/2014 } \\
X-263\end{array}$ & $\begin{array}{c}\text { New York } \\
\text { Medical College }\end{array}$ & $\begin{array}{c}\text { Centers for } \\
\text { Disease Control } \\
\text { and Prevention }\end{array}$ & & EX & $N-Y-K$ \\
\hline EPI614421 & 1 Jan 2014 & $\begin{array}{c}\text { A/Hong } \\
\text { Kong/4801/2014 } \\
X-263 A\end{array}$ & $\begin{array}{c}\text { New York } \\
\text { Medical College }\end{array}$ & $\begin{array}{c}\text { Centers for } \\
\text { Disease Control } \\
\text { and Prevention }\end{array}$ & & EX & $N-Y-K$ \\
\hline EPI614414 & 1 Jan 2014 & $\begin{array}{c}\text { A/Hong } \\
\text { Kong/4801/2014 } \\
X-263 B\end{array}$ & $\begin{array}{c}\text { New York } \\
\text { Medical College }\end{array}$ & $\begin{array}{c}\text { Centers for } \\
\text { Disease Control } \\
\text { and Prevention }\end{array}$ & & EX & $N-Y-K$ \\
\hline
\end{tabular}

GISAID: Global Initiative on Sharing All Influenza Data.

${ }^{a}$ Originating country for all isolates displayed is Hong Kong Special Administrative Region (SAR).

b The consensus sequence for clade 3 C.2a viruses is N158-Y159-T160, shown as N-Y-T for the cell (MDCK-SIAT1)-passaged A/Hong Kong/4801/2014 (clade 3 C.2a) reference virus (first row in Table) and conferring a potential gain of glycosylation. In the egg-passaged reference A/Hong Kong/4801/2014 (clade 3C.2a) reference viruses (rows 2-6 in Table), the potential glycosylation motif is lost due to reversion to clade $3 \mathrm{C} .2 \mathrm{~K} 160$.

Of the 203 clade 3 C.2a viruses that could not be $\mathrm{HI}$-characterised, all had undergone a single further passage in MDCK-SIAT1 cells at the NML to improve viral titre. Before MDCK-SIAT1 passage, 165 of the 199 (83\%) virus isolates with available sequencing information pre-MDCK-SIAT1 passage had the potential glycosylation motif associated with the clade $3 \mathrm{C} .2 \mathrm{a}$ consensus sequence $\mathrm{N}_{158}-\mathrm{Y}_{159}$-T160. After passage in MDCK-SIAT1 cells, 156 (78\%) of the 199 viruses that had sequence information available post-MDCK-SIAT1 passage had the potential glycosylation motif (Table 2).

Among viruses with available sequencing information $(n=227)$, the absence of the potential glycosylation motif at positions $158-160$ in the final virus isolate was significantly associated with the ability to $\mathrm{HI}$-characterise viruses (o with the glycosylation motif among 28 that could be HI-characterised vs. 156 (78\%) with the glycosylation motif among 199 that could not be $\mathrm{HI}$-characterised; chi-square $=70.2$, degrees of freedom $=1, p$-value $<0.001$ ).

Specific mutations at positions 158 and 160 of final virus isolates influencing the potential glycosylation motif prior to $\mathrm{HI}$ characterisation are shown in Table 3; the F159Y clade marker for 3C.2a viruses was conserved in all isolates.

\section{Discussion}

Similar to reports elsewhere, only a small proportion $(<15 \%)$ of clade 3 C.2a viruses collected through the Canadian SPSN during the 2014/15 season were able to agglutinate guinea pig erythrocytes for antigenic characterisation by $\mathrm{HI}$ assay $[1,12,13]$. All clade $3 \mathrm{C} .2 \mathrm{a}$ virus isolates that could be characterised were considered antigenically related to the $2015 / 16$ vaccine strain, although more variability in $\mathrm{HI}$ results, particularly in relation to the egg-passaged reference virus, has been reported by other surveillance systems [1]. Our findings, however, suggest that the small proportion of clade $3 \mathrm{C} .2 \mathrm{a}$ viruses that could be characterised by $\mathrm{HI}$ assay were not representative of circulating viruses with respect to the clade-defining potential glycosylation motif at positions 158-160.

We show that cell culture passage, whether in MDCK, MDCK-SIAT1 or RMK cells, that is required for $\mathrm{HI}$ characterisation, can fully or partially alter the N158-Y159-T160 sequon. This sequon in circulating clade $3 \mathrm{C} .2 \mathrm{a}$ viruses is associated with a predicted gain of glycosylation that may be relevant for antibody binding [6]. While these findings corroborate an earlier report of this effect by the ECDC [14], here we provide direct quantification and comparison of viral genomic sequences in original patient specimens compared with culture isolates, highlighting loss of the potential glycosylation 
motif as an artefact of in vitro cell culture isolation. This type of assessment has not been widely reported elsewhere, in part because most viral sequences, including those posted to public databases, are based on culture isolates and are not directly compared with primary specimens. However, understanding how viral culture impacts genetic identity before antigenic characterisation is critical to interpreting and extrapolating relatedness among vaccine and circulating strains, for the purpose of anticipating vaccine performance and for vaccine strain selection.

Limitations of our analysis include the well-recognised variability in the $\mathrm{HI}$ assay [17], and the small number of viruses that could be antigenically characterised for sequence comparison. Antigenic characterisation of a greater number of $\mathrm{A}\left(\mathrm{H}_{3} \mathrm{~N}_{2}\right)$ viruses, particularly those belonging to clade ${ }_{3}$ C.2a, may be possible through use of assays that do not rely on agglutination of erythrocytes, such as neutralisation assays $[14,18]$. The ECDC and others have considered the N158-Y159-T160 sequon to be a potential gain of glycosylation in the majority of clade 3 C.2a viruses $[1,5,6]$; the glycosylation potential of this motif based on the clade $3 \mathrm{C} .2 \mathrm{a}$ consensus sequence is 0.65 using NetNGlyc 1.0, where the threshold for glycosylation potential is 0.5 [19]. To further delineate the $\mathrm{N}$-glycosylation effect of the K160T mutation, in vitro studies should be done to specifically assess the interplay between this mutation, its resulting glycosylation potential and antibody binding at antigenic sites. We show statistically significant effects of the N158-Y159-T160 sequon on the ability to characterise viruses by $\mathrm{HI}$ assay, but it is unclear how much this potential glycosylation motif contributes to challenges in antigenic characterisation using antibody titration assays. A proportion of clade $3 \mathrm{C} .2 \mathrm{a}$ viruses (43/199; $22 \%$ in this analysis, Table 2), as well as other $\mathrm{A}\left(\mathrm{H}_{3} \mathrm{~N}_{2}\right)$ genetic subgroups, that lack or are polymorphic for this glycosylation motif have also been difficult to antigenically characterise by $\mathrm{HI}$ assay, suggesting that other factors, such as viral load and avidity to sialic acid receptors, are also likely to contribute [20]. Our goal, however, was not to investigate those factors but to assess the representativeness of clade ${ }_{3} \mathrm{C} .2 \mathrm{a}$ viruses that could be characterised by $\mathrm{HI}$ assay in relation to the majority that could not be characterised, with respect to the potential glycosylation motif at pivotal antibody binding positions $158-160$ of antigenic site $B$.

Our findings suggest that caution is warranted in extrapolating antigenic relatedness based on limited $\mathrm{HI}$ results for $\mathrm{A}\left(\mathrm{H}_{3} \mathrm{~N}_{2}\right)$ clade ${ }_{3} \mathrm{C} .2 \mathrm{a}$ viruses. Clade $3 \mathrm{C} .2 \mathrm{a}$ viruses have continued to predominate among $\mathrm{A}\left(\mathrm{H}_{3} \mathrm{~N}_{2}\right)$ detections throughout the 2015 southern hemisphere influenza season and early into the 2015/16 northern hemisphere season $[1,18]$. Despite vaccine reformulation, clade $3 \mathrm{C} .2 \mathrm{a}$ viruses still differ from the northern hemisphere 2015/16 clade 3C.3a vaccine strain by 10-12 amino acids at antigenic sites, including the same N158-Y159-T160 glycosylation motif that distinguished them from the 2014/15 vaccine [2]. For the southern hemisphere's 2016 influenza season, the WHO has recommended change to an $\mathrm{A} /$ Hong Kong/4801/2014 $\left(\mathrm{H}_{3} \mathrm{~N}_{2}\right)$-like (clade 3C.2a) representative vaccine virus [18], for which the egg-passaged reference strain bears $\mathrm{K} 160$ rather than $\mathrm{T} 160$ and thus also seems to have lost the potential glycosylation motif (Table 4). Clarifying the significance of the N158Y159-T160 potential glycosylation motif in circulating clade ${ }_{3}$ C.2a strains thus remains critical to the interpretation of antigenic relatedness and to expectations of vaccine-induced antibody protection, for which ongoing epidemiological monitoring of VE will be important.

\section{Acknowledgements}

Funding was provided by the Canadian Institutes of Health Research (CIHR grant \# TPA-90193), the British Columbia Centre for Disease Control, Alberta Health and Wellness, Public Health Ontario, Ministère de la santé et des services sociaux du Québec and the Institut national de santé publique du Québec and the Public Health Agency of Canada. The authors gratefully acknowledge the contribution of sentinel sites whose regular submission of specimens and data provide the basis of our analyses. We wish to acknowledge the coordination and technical support provided by epidemiological and laboratory staff in all participating provinces. We thank those who provided laboratory support at the British Columbia Public Health Microbiology and Reference Laboratory, the Alberta Provincial Laboratory, the Public Health Ontario Laboratory and the Laboratoire de santé publique du Québec.

\section{Conflict of interest}

Research grants for unrelated studies: GDS - GlaxoSmithKline (GSK); JG - Pfizer; MK - Roche, Merck, Gen-Probe and Siemens. SS funded by Canadian Institutes of Health Research Grant (TPA-90193).

\section{Authors' contributions}

Principal investigator (epidemiology): GDS (Québec); JAD (Alberta); DMS (National and British Columbia); ALW (Ontario). Principal investigator (laboratory): SD (Alberta); JBG (Ontario); MK (British Columbia); CM (Québec); NB and YL (national). Data analysis: CC, AE, SS, DMS. Preparation of first draft: DMS. Draft revision and approval: all.

\section{References}

1. European Centre for Disease Prevention and Control (ECDC) Influenza virus characterisation. Summary Europe, September 2015. Stockholm: ECDC; 2015. Available from: http://ecdc. europa.eu/en/publications/Publications/influenza-viruscharacterisation-september-2015.pdf

2. Skowronski DM, Chambers C, Sabaiduc S, De Serres G, Dickinson JA, Winter AL, et al. Interim estimates of 2014/15 vaccine effectiveness against influenza $A\left(\mathrm{H}_{3} \mathrm{~N}_{2}\right)$ from Canada's Sentinel Physician Surveillance Network, January 2015. Euro Surveill. 2015;20(4):21022. DOI: 10.2807/1560-7917. ES2015.20.4.21022 PMID: 25655053

3. Ndifon W, Wingreen NS, Levin SA. Differential neutralization efficiency of hemagglutinin epitopes, antibody interference, and the design of influenza vaccines.Proc Natl Acad Sci USA. 2009;106(21):8701-6. DOI: 10.1073/pnas.0903427106 PMID: 19439657

4. Popova L, Smith K, West AH, Wilson PC, James JA, Thompson LF, et al. Immunodominance of antigenic site B over site $A$ of hemagglutinin of recent $\mathrm{H}_{3} \mathrm{~N}_{2}$ influenza viruses. PLoS ONE. 
2012;7(7):e41895. DOI: 10.1371/journal.pone.0041895 PMID: 22848649

5. An Y, McCullers JA, Alymova I, Parsons LM, Cipollo JF.

Glycosylation analysis of engineered $\mathrm{H}_{3} \mathrm{~N}_{2}$ influenza A virus hemagglutinins with sequentially added historically relevant glycosylation sites.J Proteome Res. 2015;14(9):3957-69. DOI: 10.1021/acs.jproteome.5bo0416 PMID: 26202417

6. Tate MD, Job ER, Deng YM, Gunalan V, Maurer-Stroh S, Reading PC. Playing hide and seek: how glycosylation of the influenza virus hemagglutinin can modulate the immune response to infection.Viruses. 2014;6(3):1294-316. DOI: 10.3390/v6031294 PMID: 24638204

7. Koel BF, Burke DF, Bestebroer TM, van der Vliet S, Zondag GC, Vervaet G, et al. Substitutions near the receptor binding site determine major antigenic change during influenza virus evolution. Science. 2013;342(6161):976-9. DOI: 10.1126/ science.1244730 PMID: 24264991

8. Chambers BS, Parkhouse K, Ross TM, Alby K, Hensley SE. Identification of hemagglutinin residues responsible for $\mathrm{H}_{3} \mathrm{~N}_{2}$ antigenic drift during the 2014-2015 influenza season.Cell Reports. 2015;12(1):1-6. DOI: 10.1016/j.celrep.2015.06.005 PMID: 26119736

9. Centers for Disease Control and Prevention,Flannery B, Clippard J, Zimmerman RK, Nowalk MP, Jackson ML, Jackson LA, et al. . Early estimates of seasonal influenza vaccine effectiveness - United States, January 2015.MMWR Morb Mortal Wkly Rep. 2015;64(1):10-5.PMID: 25590680

10. Pebody RG, Warburton F, Ellis J, Andrews N, Thompson C, von Wissmann B, et al. Low effectiveness of seasonal influenza vaccine in preventing laboratory-confirmed influenza in primary care in the United Kingdom: 2014/15 mid-season results. Euro Surveill. 2015;20(5):21025. DOI: $10.2807 / 1560-$ 7917.ES2015.20.5.21025 PMID: 25677050

11. World Health Organization (WHO). Recommended composition of influenza virus vaccines for use in the 2015-2016 northern hemisphere influenza season. Geneva: WHO; 2015. [Accessed: 10 Dec 2015]. Available from: http://www.who.int/influenza/ vaccines/virus/recommendations/2015_16_north/en/

12. Smith S, Blanton L, Kniss K, Mustaquim D, Steffens C, Reed $C$, et al. Update: influenza activity - United States, October 4-November 28, 2015. MMWR Morb Mortal Wkly Rep. 2015;64(48):1342-8. DOI: 10.15585/mmwr.mm6448a4

13. Public Health Agency of Canada (PHAC). FluWatch: Weekly influenza reports. Ottawa: PHAC; Available from: http:// healthycanadians.gc.ca/publications/diseases-conditionsmaladies-affections/fluwatch-2015-2016-51-52-surveillanceinfluenza/index-eng.phphttp://

14. European Centre for Disease Prevention and Control (ECDC). Influenza virus characterization. Summary Europe, February 2015. Stockholm: ECDC; 2015. Available from: http://ecdc. europa.eu/en/publications/Publications/ERLI-Net-reportFebruary-2015.pdf

15. Lin YP, Gregory V, Collins P, Kloess J, Wharton S, Cattle N, et al. Neuraminidase receptor binding variants of human influenza $A\left(\mathrm{H}_{3} \mathrm{~N}_{2}\right)$ viruses resulting from substitution of aspartic acid 151 in the catalytic site: a role in virus attachment? J Virol. 2010;84(13):6769-81. DOI: 10.1128/JVI.00458-10 PMID 20410266

16. Oh DY, Barr IG, Mosse JA, Laurie KL. MDCK-SIAT1 cells show improved isolation rates for recent human influenza viruses compared to conventional MDCK cells.J Clin Microbiol. 2008;46(7):2189-94. DOI: 10.1128/JCM.00398-08 PMID: 18480230

17. Katz JM, Hancock K, Xu X. Serologic assays for influenza surveillance, diagnosis and vaccine evaluation. Expert Rev Anti Infect Ther. 2011;9(6):669-83. DOI: 10.1586/eri.11.51 PMID: 21692672

18. World Health Organization. Recommended composition of influenza virus vaccines for use in the 2016 southern hemisphere influenza season. Geneva: WHO; 2015. Available from: http://www.who.int/influenza/vaccines/virus/ recommendations/2016_south/en/

19. Gupta R, Jung E, Brunak S. Prediction of N-glycosylation sites in human proteins. NetNGlyc 1.0. Denmark: Center for Biological Sequence Analysis. [Accessed: 10 Dec 2015]. Available from: http://www.cbs.dtu.dk/services/NetNGlyc/

20. Lin YP, Xiong X, Wharton SA, Martin SR, Coombs PJ, Vachieri $S G$, et al. Evolution of the receptor binding properties of the influenza $A\left(\mathrm{H}_{3} \mathrm{~N}_{2}\right)$ hemagglutinin. Proc Natl Acad Sci USA. 2012;109(52):21474-9. DOI: 10.1073/pnas.1218841110 PMID: 23236176

\section{License and copyright}

This is an open-access article distributed under the terms of the Creative Commons Attribution (CC BY 4.0) Licence. You may share and adapt the material, but must give appropriate credit to the source, provide a link to the licence, and indicate if changes were made.

This article is copyright of the authors, 2016. 